\title{
Socio-Demografic Characteristics Associated with Loss to Follow Up of Antiretroviral Therapy Among HIV and AIDS Patients in Semarang City, Central Java Province: A Case Control Study
}

\author{
Sutini $^{1}$, Widya Hary Cahyati ${ }^{2}$, Sri Ratna Rahayu ${ }^{3}$, Muchlis Achsan Udji Sofro ${ }^{4}$, Nur \\ Fahanah $^{5}$, Setyo Pramudo ${ }^{6}$, 'Selamet Hidayat ${ }^{7}$, Tuti Susilowati ${ }^{8}$, Farid Agushybana ${ }^{9}$, Slamet \\ Riyadi $^{10}$ \\ \{tinihernowo@gmail.com ${ }^{1}$, widyahary27@gmail.com², s.ratnarahayu@gmail.com ${ }^{3}$ \\ muchlis.aus@gmail.com ${ }^{4}$, nurfarhanahams@gmail.com ${ }^{5}$, dr.pramudo2012@gmail.com ${ }^{6}$, \\ hidayat.selamet@gmail.com ${ }^{7}$, iyya_salaman@yahoo.co.id ${ }^{8}$, hybana@gmail.com ${ }^{9}$, \\ justslam@gmail.com $\left.{ }^{10}\right\}$ \\ Universitas Negeri Semarang, Semarang, Indonesia ${ }^{123}$, \\ Diponegoro University, Semarang, Indonesia ${ }^{456789}$, \\ Katholik Soegijapranata University, Semarang, Indonesia ${ }^{10}$
}

\begin{abstract}
Loss to follow-up (LTFU) of clients from antiretroviral therapy (ART) has a great negative impact on the immunological benefits of ART, and increased acquired immune deficiency syndrome related morbidity and mortality. The purpose of this study was to analyze socio-demographic characteristics related to LTFU among HIV and AIDS patients in Semarang City. A case-control study was carried out at Hospitals and Primary Health Centre. Patients who did not take anti-retroviral for 3 months were defined as LTFU while those regularly take anti retro viral for 3 months became the controls. The total sample of the research were 134 respondents obtained by purposive sampling technique. Chi square and logistic regression tests were performed to analyze factors associated with LTFU. The multivariate analyses showed the most dominant factors that influence with LTFU was education level $(\mathrm{OR}=6.27 .95 \% \mathrm{CI}: 2.29,17.09)$. Intervention on literacy program should be emphasized to patients who are about to start and during the ART program.
\end{abstract}

Keywords: Socio-demographic characteristics, Loss to follow up, Antiretroviral Treatment, HIV and AIDS.

\section{Introduction}

Human immunodeficiency virus (HIV) infection remains the leading cause of morbidity and mortality throughout the world. By the end of 2018, the World Health Organization (WHO) estimated that globally about 37.9 million people were living with HIV (PLHIV) and about 23.3 million (62\%) of the PLHIV patients received antiretroviral therapy (ART) [1]. Antiretroviral therapy has significantly reduced mortality and improved the life expectancy of HIV infected patients but the success still critically depends on regular patient follow up [2]. 
To accelerate epidemic control, the United Nations Joint Program on HIV/AIDS (UNAIDS) launched the 90-90-90 campaign in 2014. One of the targets was to achieve viral suppression among $90 \%$ of patients receiving ART by 2020 . The other targets were ensuring that $90 \%$ of the people living with HIV know their HIV status and $90 \%$ of those who are diagnosed with HIV infection receive sustained ART [3].

Treatment as prevention studies have demonstrated effectiveness of ART in preventing new HIV infections [3],[4], [5], [6], therefore, increasing ART coverage has public health benefits including reduction of new HIV infections through reduced community viral loads [7].

Loss to follow up of clients from ART have a great negative impact on the immunological benefits of ART, increased acquired immune deficiency syndrome (AIDS) related morbidity, mortality and hospitalization and it also resulted in serious consequences such as discontinuation of treatment, drug toxicity, treatment failure due to poor adherence and drug resistance[8]. Thus, high rates of LTFU ART from treatment programs pose a serious challenge to program implementers and constitutes an inefficient use of scarce treatment resources[9].

Loss to follow-up (LTFU) defined as not taking ART refill for 3 months or longer from the last attendance for refill and not yet classified as dead or transferred-out [10]. The percentage of loss of follow up in the first year of ARV therapy is an indicator of the success of ART. WHO has a target loss to follow-up in the first year of treatment is <20\% [11]. LTFU ART among HIV and AIDS patients associated with ART adherence is a problem in Semarang City. Report on HIV care and ART from Semarang City Health Office from 1995 2019, there were 924 PLHIV that LTFU (21\%).

Different studies showed that LTFU ART is associated with socio-demographic baseline factors like sex education [12], [13], age [12], [14] level of education [15], [16], [17], [18], [19], marital status [20], [17], employment status [21], [22], [23], [24], distance from the health facility[10], [25], [21], [26].

Study at Dr. Kariadi Hospital in Semarang City by Rosiana in 2014 showed that factors related with patients who stopped ART were due to work or daily activities, lack of counselling and testing clinics, and lack of social support. [27]. Study at Dr. Sardjito Hospital in Yogyakarta Province in 2016 showed that occupation as students, distance between home and health services $\geq 10 \mathrm{~km}$ and the use of health insurance were factors that influenced LTFU [28]. Socio-demographic factors including accessibility to services are some of the predictors causing LTFU [29].

\section{Method}

Design of this study was observational with case-control study. The population was HIV and AIDS patients who were recorded in HIV care, support and treatment services at the primary health centers and hospitals in Semarang City, Central Java Province, Indonesia during 2016-2018 period who adhered on ART and LTFU. Patients who did not take antiretroviral for 3 months were defined as LTFU while those regularly take anti retro viral for 3 months became the controls. The study samples consisted of 67 cases and 67 controls. The sampling technique was purposive sampling. The independent variables of this study were age, sex, marital status, level of education, employment status, distance from the health facility. The dependent variables of the study was HIV and AIDS patients who are loss to 
follow up of ART. Data collection was carried out by interviews using structured questionnaires. Univariate analysis was carried out to describe baseline socio-demographic characteristics of the study subjects using simple frequency distribution. Chi-squared tests were used to measure the significance of differences in socio-demographic characteristic between cases and controls. Multivariate analysis using a logistic regression was performed to identify factors associated with LTFU. The criteria for selection of variables possible for inclusion in multivariable analysis were based on p-value of less than $5 \%$. The strength of association was measured using matched Odds Ratios (OR).

\section{Result}

Table 1. Baseline of socio-demographic characteristics of study participants in Semarang City

\begin{tabular}{|c|c|c|c|c|c|c|c|}
\hline \multirow{2}{*}{ Variables } & \multicolumn{2}{|c|}{ Total } & \multicolumn{2}{|c|}{ Cases } & \multicolumn{2}{|l|}{ Control } & \multirow[t]{2}{*}{ P-value } \\
\hline & $\mathbf{N}$ & $\%$ & $\mathbf{N}$ & $\%$ & $\mathbf{N}$ & $\%$ & \\
\hline \multicolumn{8}{|l|}{ Age in years } \\
\hline 18-50 & 124 & 92,5 & 64 & 95,5 & 60 & 85,6 & 0,189 \\
\hline$>\mathbf{5 0}$ & 10 & 7,5 & 3 & 4,5 & 7 & 10,4 & \\
\hline \multicolumn{8}{|l|}{ Gender } \\
\hline Male & 89 & 66,4 & 44 & 65,7 & 45 & 67,2 & 0,855 \\
\hline Female & 45 & 33,6 & 23 & 34,3 & 22 & 32,8 & \\
\hline \multicolumn{8}{|l|}{$\begin{array}{l}\text { Educational } \\
\text { Status }\end{array}$} \\
\hline Low Education & 81 & 60,4 & 56 & 83,6 & 25 & 37,3 & $0,000 *$ \\
\hline $\begin{array}{l}\text { High } \\
\text { Education }\end{array}$ & 53 & 39,6 & 11 & 16,4 & 42 & 62,7 & \\
\hline \multicolumn{8}{|l|}{$\begin{array}{l}\text { Employment } \\
\text { status }\end{array}$} \\
\hline Unemployed & 61 & 45,5 & 19 & 28,4 & 42 & 62,7 & \\
\hline Employed & 73 & 54,5 & 48 & 71,6 & 25 & 37,3 & $0,000 *$ \\
\hline \multicolumn{8}{|l|}{ Marital Status } \\
\hline Unmarried & 92 & 68,7 & 43 & 64,2 & 49 & 73,1 & 0,264 \\
\hline Married & 42 & 31,3 & 24 & 35,8 & 18 & 26,9 & \\
\hline \multicolumn{8}{|l|}{$\begin{array}{l}\text { Distance from } \\
\text { the health } \\
\text { facility }\end{array}$} \\
\hline$\leq 5 \mathrm{kms}$ & 71 & 53,0 & 43 & 64,2 & 28 & 41,8 & $0,009 *$ \\
\hline$>5 \mathrm{kms}$ & 63 & 47,0 & 24 & 35,8 & 39 & 58,2 & \\
\hline
\end{tabular}

*Note: P-value $<0.05$ is considered significant

At the end of study most $(92.5 \%)$ of study subjects were aged between $18-50$ years and predominantly males $(66,4 \%)$. Most of study subjects $(60.4 \%)$ have low educational status. For the employment, 54,5\% were employed and $68.7 \%(\mathrm{n}=92)$ were married. The majority distance from the health facility $\leq 5 \mathrm{~km}(53 \% ; n=71)$. The majority $(67,2 \% ; n=45)$ of patients who were LTFU were also males. 
When we compared cases with controls, the educational status $(\mathrm{p}=0.000)$, employment status $(p=0.000)$ and distance from the health facility $>5 \mathrm{kms}(\mathrm{p}=0.009)$ were significantly different between cases and controls. A higher proportion of LTFU individuals $(83.6 \%)$ has less education (no education, primary and secondary education) compared to those who were still in care $(16.4 \%)$. Higher proportion of LTFU individuals was employed (71.6\%) compared to those who were still in care $(28.4 \%)$. Moreover, a higher proportion of LTFU individuals live more distance from health facility (64.2\%) compared to those who were still in care $(35.8 \%)$ (Table 1$)$.

Table 2. Dominant Socio-demographic characteristics associated with loss to follow up at Semarang.

\begin{tabular}{llll}
\hline Multivariat analysis & OR & 95\% CI & P-Value \\
\cline { 1 - 1 } & & lower $\quad$ upper & \\
\cline { 1 - 2 } & &
\end{tabular}

Educational Status

\begin{tabular}{lcccc}
\hline Low Education & 6.270 & 2.299 & 17.098 & $\mathbf{0 , 0 0 0 *}$ \\
\hline High Education & & & & \\
\hline Employment status & & & & \\
\hline Unemployed & & & & \\
\hline Employed & 0.250 & 0.099 & .632 & 0,003 \\
\hline Distance from the health facility & & & & \\
\hline$\leq 5 \mathrm{kms}$ & 1.455 & 0.578 & 3.663 & 0,426 \\
\hline$>5 \mathrm{kms}$ & & & & \\
\end{tabular}

* Note: P-value $<0.05$ is considered significant

As shown in Table 2, the results of the multivariat analysis showed that the low education has six times the odds of being LTFU compared to high education (OR $=6.27$ (95\% CI: 2.29 - 17.06)). Employed patients has $71 \%$ odds of being LTFU compared to those who were unemployed (adjusted OR $=0.25 .95 \% \mathrm{CI}: 0.09,0.63$ ). Patients who lived $\leq 5 \mathrm{kms}$ from health facility has an adjusted odds ratio for LTFU of 1.45 (95\% CI: 0.57-3.66), when compared to patients who lived $>5 \mathrm{kms}$ from health facility.

\section{Discussion}

\subsection{Age}

The results of the bivariate analysis showed that the LTFU aged range from 19-50 years but not statistically significant. Age related to a person's psychological condition where psychological factors greatly influence the continuation of ART. Motivation and one's own ability to behave adherently to access to ART are part of the psychological associated with young age [30]. Research at Dr Kariadi Hospital in Semarang showed that patients aged <30 years influence the incidence of loss to follow up [27]. Research at the Amertha Clinic of the Kerti Praja Foundation, Bali, age <32 years affects loss to follow up [31]. 


\subsection{Gender}

Gender is one of the factors associated with the occurrence of LTFU ART among people living with HIV and AIDS.The results of this research showed that LTFU ART patients were majority males $(65,7 \%)$ although it was not statistically significant. LTFU ART was dominant in male [32], [33], [34]. Male patients were more prone to LTFU because they worked or often moved to other region [19], Male patients have variations in mobility and a higher risk of drug abuse that can disrupt with adherence to ART so they are more likely to becomeLTFU [17]. The condition is different for women who are more likely to visit health care facilities than men to get reproductive services and child health services [34]. Women seek immediate care because they are the primary caregivers in the family and feel they have a greater responsibility to stay healthy. Men are more likely to experience loss to follow up if they have advanced disease, whereas women are more likely to lose to follow up if their CD4 cell counts are high, this shows that loss to follow up in men is likely due to disease that gets worse or death [21].

\subsection{Educational Status}

Education is also associated with LTFU ART even though education is not in line with one's behavior. The results of the bivariate analysis showed that the LTFU ART patients were mostly has low education which statistically significant $(p=0,000)$. The study found OR of 6,2 means that a patient with low education has six times the odds of being LTFU ART compared to a patient with high education. This finding was similar with studies conducted in India ([17], Africa [18] [19], Ethopia ([15]. Patients with low levels of education find it difficult to understand pre-counseling which includes information of HIV infection, treatment purposes, risks and benefits of therapy, side effects, resistance and comprehensive adherence [35]. Education < 16 years is significantly related to loss to follow up. The shorter the education time, the risk of LTFU is also greater. People with low education may have employment-related problems such as not having time to take a rest from work and clinic visits [36]. A retrospective observational study at primary health clinic in Masaka Uganda also showed patients with low education associated with higher LTFU, because patients might have difficulty reading text reminder messages and some communication, information and other educational materials in health facilities that emphasize the need for further care [37]. Patients who have low education are more likely to failure treatment because they do not understand treatment instructions and end in death [38].Thus, treatment failure was a significant predictor of survival or mortality in HIV patients taking antiretroviral drugs.

\subsection{Employment Status}

This study found that employment status is related to the incidence of LTFU $(\mathrm{p}=0,000)$. This study was obtained from respondents who were asked related to financial assistance to access health services and also the feasibility to obtain permission from the 
employers to visit health facilities. These constraints caused the approval of PLWHA in accessing care services to be low and end up increasing LTFU.

The results of this study are consistent with studies in Ethiopia that showed $18.2 \%$ of HIV patients always skip treatment or do not take medication for busy reasons [22]. Likewise, a study in Kenya explained that $43.8 \%$ of HIV patients did not take medication due to busy work factors [21]. Study in Africa explains that LTFU was higher in someone who works every day through the day at work and does not have enough time to come to a health facility for follow up. Because of the nature of their work, they are also more mobile and do not have a constant workplace ending with LTFU [19]. Five LTFU patients (23.8\%) said that they did not take ARV drugs because they were busy working and had workplaces outside the city so they could not visit the VCT clinic at RSUP Dr Kariadi [27]. Similarly, the Helen Bygrave et al cohort study in South Africa found treatment failure rates among migrant workers compared with the general population in the first year of treatment, with significant differences observed after one year. Mobility is recognized as the reason why patients became LTFU [39]. Study in Thailand showed that $48 \%$ of patients skipped taking drugs in the health service due to work factors and also they are ashamed to their supervisors and the workplace environment when they take ARV. So, work-related obstacles are one of the factors that cause them to disappear and skip doses in the use of ARV[23].

\subsection{Marital Status}

This study showed that not having partner is higher $(64,2 \%)$ in the LTFU patients but was not statistically significant. Patients who do not have a partner are more likely to become LTFU because they do not have a support person that is negatively affected by HIVrelated stigma [40]. Patients who were unmarried and divorced are mostly LTFU compared to patients who were married [17]; [10]; [32]. Those without partners are less likely to have support system and are thus more likely to be negatively affected by HIV-related stigma and this has proven to be a barrier to adherence and retention in care and treatment [41] [42].

\subsection{Distance from the health facility}

This study showed distance of residence to health care facility was significantly associated with LTFU ( $\mathrm{p}=0.009)$. Majority of LTFU patients was live $\leq 5 \mathrm{kms}$ from health facilities. There might be other factors that influence the occurrence of LTFU which related to daily activities. The result of this study was not in accordance with some of the studies which explain that longer distances from health facilities reduced client access because they have to spend more money and time for travel. Although most of HIV services are offered free of charge, indirect costs are a barrier to client retention in care. The same study also states that distance is a predictor of LTFU (> $5 \mathrm{~km}$ vs $<1 \mathrm{~km}$ : aHR $=2.695 \%$ CI 1.9-3.7 with $\mathrm{p}<0.01$ ) [40]. Other studies showed longer distances, long travel times and high transportation costs are the main barriers to access to HIV care ([25], [21], [26]. Longer distance to the clinic is defined by more than $5 \mathrm{kms}(\mathrm{aHR}=1.25,95 \%$ CI 1,001.55) [10]. Research in Nairobi- Kenya showed that patients who lived between $5-10 \mathrm{kms}$ from the research clinic has a doubled increase in LTFU compared to those who were within $5 \mathrm{kms}$ away (HR $=2.17 ; 95 \% \mathrm{CI}: 1.09$, 4.34) [43]. 


\section{Conclusion}

People living with HIV and AIDS who has low education was the major significant factor for LTFU in Semarang City. Focusing on counseling and education will help in increasing knowledge and awareness for HIV patients in adhering to the ART and taking medication according to the doctor's instructions.

\section{References}

[1] World Health Organization, "World Health Organization. Global Health Observatory (GHO) data. HIV/AIDS,” https://www.who.int/gho/hiv/en/, 2017. .

[2] M. T. May et al., "Impact on life expectancy of HIV-1 positive individuals of CD4R cell count and viral load response to antiretroviral therapy," Aids, vol. 28, no. 8, pp. 1193-1202, 2014.

[3] UNAIDS, “To help end the AIDS epidemic," United Nations, p. 40, 2014.

[4] E. Raymond et al., "new england journal. SCD-Heft.," Heart Fail., vol. 364, no. 6, pp. 225-237, 2011.

[5] M. S. Cohen, M. McCauley, and T. R. Gamble, "HIV treatment as prevention and HPTN 052," Curr. Opin. HIV AIDS, vol. 7, no. 2, pp. 99-105, 2012.

[6] B. Grinsztejn et al., "Effects of early versus delayed initiation of antiretroviral treatment on clinical outcomes of HIV-1 infection: Results from the phase 3 HPTN 052 randomised controlled trial," Lancet Infect. Dis., vol. 14, no. 4, pp. 281-290, 2014.

[7] W. R. Shipley, R. D. Hammer, W. J. Lennington, and W. R. Macon, "Paraffin immunohistochemical detection of CD56, a useful marker for neural cell adhesion molecule (NCAM), in normal and neoplastic fixed tissues," Appl. Immunohistochem. Mol. Morphol., vol. 5, no. 2, pp. 87-93, 1997.

[8] H. Gesesew, B. Tsehaineh, D. Massa, A. Tesfay, H. Kahsay, and L. Mwanri, "The role of social determinants on tuberculosis/HIV co-infection mortality in southwest Ethiopia: A retrospective cohort study," BMC Res. Notes, vol. 9, no. 1, pp. 4-11, 2016.

[9] M. N. Mberi, L. R. Kuonza, N. M. Dube, C. Nattey, S. Manda, and R. Summers, "Determinants of loss to follow-up in patients on antiretroviral treatment, South Africa, 2004-2012: A cohort study," BMC Health Serv. Res., vol. 15, no. 1, pp. 1-11, 2015.

[10] C. E. Bekolo, J. Webster, M. Batenganya, G. E. Sume, and B. Kollo, “Trends in mortality and loss to follow-up in HIV care at the Nkongsamba Regional hospital, Cameroon," BMC Res. Notes, vol. 6, no. 1, 2013.

[11] D. A. Tran, A. D. Ngo, A. Shakeshaft, D. P. Wilson, and C. Doran, "Trends in and Determinants of Loss to Follow Up and Early Mortality in a Rapid Expansion of the Antiretroviral Treatment Program in Vietnam : Findings from 13 Outpatient Clinics," 
vol. 8, no. 9, 2013.

[12] S. B. Asiimwe, M. Kanyesigye, B. Bwana, S. Okello, and W. Muyindike, "Predictors of dropout from care among HIV-infected patients initiating antiretroviral therapy at a public sector HIV treatment clinic in sub-Saharan Africa," BMC Infect. Dis., vol. 16, no. 1, pp. 1-10, 2016.

[13] W. Seifu, W. Ali, and B. Meresa, "Predictors of loss to follow up among adult clients attending antiretroviral treatment at Karamara general hospital, Jigjiga town, Eastern Ethiopia , 2015 : a retrospective cohort study,” pp. 1-8, 2018.

[14] M. A. Assemie, K. F. Muchie, and T. A. Ayele, "Incidence and predictors of loss to follow up among HIV-infected adults at Pawi General Hospital, northwest Ethiopia: Competing risk regression model,” BMC Res. Notes, vol. 11, no. 1, pp. 1-6, 2018.

[15] B. L. Hønge et al., "Loss to follow-up occurs at all stages in the diagnostic and followup period among HIV-infected patients in Guinea-Bissau: A 7-year retrospective cohort study," BMJ Open, vol. 3, no. 10, pp. 1-10, 2013.

[16] P. Z. Akilimali et al., "Disclosure of HIV status and its impact on the loss in the follow-up of HIV-infected patients on potent anti-retroviral therapy programs in a (post-) conflict setting: A retrospective cohort study from goma, Democratic Republic of Congo," PLoS One, vol. 12, no. 2, pp. 1-13, 2017.

[17] G. Alvarez-uria, P. K. Naik, R. Pakam, and M. Midde, "Factors associated with attrition, mortality, and loss to follow up after antiretroviral therapy initiation: data from an HIV cohort study in India," vol. 1, pp. 1-8, 2013.

[18] R. Bucciardini et al., "Predictors of attrition from care at 2 years in a prospective cohort of HIVinfected adults in Tigray, Ethiopia," BMJ Glob. Heal., vol. 2, no. 3, pp. $1-9,2017$.

[19] K. G. Marson et al., "Male, Mobile, and Moneyed: Loss to Follow-Up vs. Transfer of Care in an Urban African Antiretroviral Treatment Clinic," PLoS One, vol. 8, no. 10, pp. 2-9, 2013.

[20] S. T. Meloni et al., "Time-Dependent Predictors of Loss to Follow-Up in a Large HIV Treatment Cohort in Nigeria," 2012.

[21] V. Ochieng-ooko et al., "Influence of gender on loss to follow-up in a large HIV treatment programme in western Kenya," no. April, pp. 681-688, 2010.

[22] A. Amberbir, K. Woldemichael, S. Getachew, B. Girma, and K. Deribe, "Predictors of adherence to antiretroviral therapy among HIV-infected persons: A prospective study in Southwest Ethiopia," BMC Public Health, vol. 8, pp. 1-9, 2008.

[23] N. Han, W. Phoolcharoen, and U. Perngparn, “Antiretroviral Drug Taking In Hiv Positive Among Myanmar Migrants In Central Area Of Thailand,” vol. 23, pp. 33-36, 2009.

[24] N. Mekonnen, M. Abdulkadir, E. Shumetie, and A. G. Baraki, "Incidence and predictors of loss to follow - up among HIV infected adults after initiation of first line anti - retroviral therapy at University of Gondar comprehensive specialized Hospital Northwest Ethiopia , 2018 : retrospective follow up study," BMC Res. Notes, pp. 1-7, 
2019.

[25] B. Amuron et al., "Mortality and loss-to-follow-up during the pre-treatment period in an antiretroviral therapy programme under normal health service conditions in Uganda," BMC Public Health, vol. 9, pp. 1-6, 2009.

[26] E. Losina et al., "Cost-effectiveness of preventing loss to follow-up in HIV treatment programs: A Côte d'Ivoire appraisal," PLoS Med., vol. 6, no. 10, 2009.

[27] A. Rosiana and M. Sofro, "Faktor - Faktor Yang Mempengaruhi Lost To Follow-Up Pada Pasien Hiv/Aids Dengan Terapi Arv Di Rsup Dr Kariadi Semarang," J. Kedokt. Diponegoro, vol. 3, no. 1, 2014.

[28] A. L. Susyanty, R. S. Handayani, and S. Sugiharti, "Keterjangkauan Biaya untuk Mendapatkan Pengobatan pada Anak dengan HIV AIDS dan Infeksi Oportunistik," Media Penelit. dan Pengemb. Kesehat., vol. 27, no. 3, pp. 161-168, 2017.

[29] T. M. Berheto, D. B. Haile, and S. Mohammed, "Predictors of Loss to follow-up in Patients Living with HIV / AIDS after Initiation of Antiretroviral Therapy," vol. 6, no. 9, pp. 453-459, 2014.

[30] A. Wringe, M. Roura, M. Urassa, J. Busza, V. Athanas, and B. Zaba, "Doubts, denial and divine intervention: Understanding delayed attendance and poor retention rates at a HIV treatment programme in rural Tanzania," AIDS Care - Psychol. Socio-Medical Asp. AIDS/HIV, vol. 21, no. 5, pp. 632-637, 2009.

[31] D. N. Widyanthini, A. A. S. Sawitri, and D. N. Wirawan, "Analisis Retrospektif Longitudinal: Loss to Follow Up saat Menjalani Terapi Antiretroviral di Yayasan Kerti Praja Bali Tahun 2002-2012," Public Heal. Prev. Med. Arch., vol. 2, no. 1, p. $81,2014$.

[32] V. Mugisha et al., "Determinants of Mortality and Loss to Follow-Up among Adults Enrolled in HIV Care Services in Rwanda," vol. 9, no. 1, pp. 1-9, 2014.

[33] A. Aliyu et al., "Predictors of loss to follow-up in art experienced patients in Nigeria: A 13 year review (2004-2017)," AIDS Res. Ther., vol. 16, no. 1, pp. 1-9, 2019.

[34] S. Odafe et al., "Patients' demographic and clinical characteristics and level of care associated with lost to follow-up and mortality in adult patients on first-line ART in Nigerian hospitals," J. Int. AIDS Soc., vol. 15, no. 2, pp. 1-9, 2012.

[35] H. Karcher, A. Omondi, J. Odera, A. Kunz, and G. Harms, "Risk factors for treatment denial and loss to follow-up in an antiretroviral treatment cohort in Kenya," vol. 12, no. 5, pp. 687-694, 2007.

[36] S. Krishnan et al., "Incidence rate of and factors associated with loss to follow-up in a longitudinal cohort of antiretroviral-treated HIV-infected persons: An AIDS clinical trials group (ACTG) longitudinal linked randomized trials (ALLRT) analysis," HIV Clin. Trials, vol. 12, no. 4, pp. 190-200, 2011.

[37] J. Kiwanuka, J. M. Waila, M. M. Kahungu, J. Kitonsa, and N. Kiwanuka, "Determinants of loss to follow-up among HIV positive patients receiving antiretroviral therapy in a test and treat setting: A retrospective cohort study in Masaka, Uganda," PLoS One, vol. 15, no. 4, pp. 1-17, 2020. 
[38] T. Girum, F. Yasin, A. Wasie, T. Shumbej, F. Bekele, and B. Zeleke, "The effect of " universal test and treat 'program on HIV treatment outcomes and patient survival among a cohort of adults taking antiretroviral treatment ( ART ) in low income settings of Gurage zone, South Ethiopia," AIDS Res. Ther., pp. 1-9, 2020.

[39] H. Bygrave et al., "Trends in loss to follow-up among migrant workers on antiretroviral therapy in a community cohort in Lesotho," PLoS One, vol. 5, no. 10, pp. 3-7, 2010.

[40] A. S. Hassan, K. L. Fielding, N. M. Thuo, H. M. Nabwera, E. J. Sanders, and J. A. Berkley, "Early loss to follow-up of recently diagnosed HIV-infected adults from routine pre-ART care in a rural district hospital in Kenya: a cohort study," Trop. Med. Int. Heal., vol. 17, no. 1, pp. 82-93, 2012.

[41] S. Merten, E. Kenter, O. McKenzie, M. Musheke, H. Ntalasha, and A. Martin-Hilber, "Patient-reported barriers and drivers of adherence to antiretrovirals in sub-Saharan Africa: A meta-ethnography," Trop. Med. Int. Heal., vol. 15, no. SUPPL. 1, pp. 1633, 2010.

[42] M. McGuire et al., "Vital status of pre-ART and ART patients defaulting from care in rural Malawi,” Trop. Med. Int. Heal., vol. 15, no. SUPPL. 1, pp. 55-62, 2010.

[43] N. J. Conley et al., "Distance from home to study clinic and risk of follow-up interruption in a cohort of HIV-1-discordant couples in Nairobi, Kenya," PLoS One, vol. 7, no. 8, pp. 4-11, 2012. 